\title{
Property and Construction Professions: The views of industry leaders
}

Anthony Mills, (Senior Lecturer, Department of Architecture, Building and Planning, University of Melboume, Australia)

\section{ABSTRACT}

The role of professionals has changed significantly, and so too should the role of professional societies. The future is very unclear, and it is likely that professional societies will continue to change and adapt. But what is their role today; is it to provide leadership, serve their members, or promote their professions? These questions were put to a number of construction industry leaders to seek their views. The presidents of three professional institutes and a government regulator for the construction industry were approached and their opinions recorded. Each interviewee was chosen because of their leadership role within the property and construction industries. Using an informal exploratory interview approach each respondent discussed issues facing their professional society. The results show that indemnity insurance, continuing professional development, and public recognition were key concerns.

Keywords: Professions, property, construction, Australia, Professional Societies.

\section{INTRODUCTION: WHAT IS A PROFESSION?}

History has shown that a profession is a type of occupation that has particular characteristics. Eccles (2002) cites Millerson who defines a profession as 'a type of higher grade non-manual occupation with both subjectively and objectively recognised status, possessing a well defined area of study or concern and providing a definite service after advanced education and training'.

According to Eccles (2002) it is generally accepted that there are four differing methods of attempting to define and describe the concept of a profession: by trait; by process; by usage; and as a labour market phenomenon. The most obvious means of definition is by universal definition achieved by describing a set of characteristics that delineate a profession. Criteria such as ownership of a body of knowledge, a code of ethics and (self-) regulation are typically included within such a definition, but the extent to which it is possible to develop such universally applicable ideals has become regarded as increasingly problematic.

Eccles (2002) believes that a more appropriate approach has been to investigate the process, or history, of 'professionalisation' in the assumption that the desire to become a professional is more important than conforming to a simple series of characteristics. Similarly, the concept of professionalism can be regarded as one of self-definition and the usage of the term by the parties themselves in a context becomes the centre of investigation. The last school of thought sees the professions as a phenomenon of the labour market, a simple labour aristocracy or group of workers provided with an advantage by some twist of fate or quirk of capitalist economics.

According to Hughes (2003), since the introduction of the Restrictive Trade Practices Act of 1982 (in the UK), which outlawed mandatory fee scales, professionals could undercut each other and bid competitively for work. Hughes believes that professional institutions now occupy themselves as qualifying bodies, providers of career development courses, and writers of standard procedure manuals.

This paper is primarily concerned with the views of industry leadership engaged in property and construction-related professions. The objective of the research was to determine what industry leaders consider the most important function of their professional institute, or role as the industry leading regulator. The following research aims were considered appropriate:

The perception of public standing of the professions, including the role professional societies have in promoting services of their members;

Mechanisms used to ensure professions remain relevant to the community; and

The way in which professional societies benefit their members.

While it is acknowledged that the above list of aims is not exhaustive, each point was raised to focus their attention on a manageable number of issues. The role of professional societies should be most clearly understood by their presidents who are directly involved in the day-to-day running of an institute. It became obvious that each industry leader recalled particular initiatives that responded to one of the above questions. For instance, one of the mechanisms commonly used by professional societies to ensure their members remain relevant to the community is through a continuing professional development program.

\section{RESEARCH METHODOLOGY}

The purpose of this section is to determine the methods available to examine the aims mentioned above. There are two distinct generic philosophical research approaches: positivist, and phenomenological or interpretative. In its purest form, the main assumption of the positivist approach is that there exists an objective truth that can be revealed through the use of scientific methods. This type of research starts with a hypothesis and then data is collected to test its validity. 
The interpretative approach is different; instead it uses detailed observation in order to explain why there are different outcomes or experiences. This method focuses its attention on observing outcomes, and is often used in social research. The most important purpose of this style of research is to generate theory, based on observing or interpreting situations or occurrences (Easterby-Smith et al., 1991).

The research in this paper follows the interpretative approach; which often involves the collection of qualitative data. Interviewing is often the best approach to obtain exploratory information, as the respondents' responses can be probed more fully (Fowler, 1984). Due to the depth of information required in this research the use of interviews was justified.

Both semi-structured and unstructured interviews have been postulated as suitable techniques for obtaining exploratory information (MRS, 1973). In this case, semi-structured interviews were considered more appropriate for this research. During the interviews, each respondent was asked a similar set of questions, and then given the opportunity to expand and/or develop their thoughts on the factors affecting their views.

This was considered the most appropriate mechanism for eliciting the knowledge of the industry leaders. A group of four people was selected for the interviews; all were obtained from personal contacts. The participating organizations were all from property and construction related organizations and therefore are exposed to similar external environments. The persons approached were:

President, Royal Australian Institute of Architects, Victoria (RAIA)

President, Australian Property Institute, Victoria (API)

President, Engineers Australia, Victoria Chapter, (EA) The Building Commissioner, Government of Victoria (BC)

All interviewees were given a similar set of open-ended questions designed to investigate the role of professional societies, the questions were related to the following:

How does your organization promote recognition and status of the profession to the community?

What is your organization's role in maintaining the ongoing credibility of members?

What does your organization do to demonstrate the benefits of membership?

The interviews were each approximately forty to fifty minutes in duration. Interviews were tape recorded, and transcripts were produced. The transcript of each interview was returned to the interviewee for validation. Once validated the transcript was printed in a professional journal (See Table 1).
Analysis of the transcripts showed that each interview transcript was approximately the same length. The results (Table 1) show that that the average transcript contained 2,275 words. The transcripts were then coded to reflect three themes: public recognitions and status, continuing professional development, and professional indemnity insurance.

\section{RESULTS AND DISCUSSIONS}

The word count for each interview is shown inTable 1. Each interviewee was asked a similar set of questions but the emphasis that they placed on the questions varied. Consequently, each person tended to focus on only one or two aspects of 'professionalism'. The full interview transcript of each interview was published in the official journal of the Australian Institute of Quantity Surveyors, The Building Economist, at the dates shown in Table 1 (Mills, 2002a; Mills, 2002b; Mills, 2003a; and Mills, 2003b).

\begin{tabular}{|l|l|r|l|}
\hline Interviewee & Organization & Word Count & Transcript \\
\hline Elli Gianni & $\begin{array}{l}\text { Royal Australian } \\
\text { Institute of Architects }\end{array}$ & 2,200 & $\begin{array}{l}\text { Reference } \\
\text { September, } \\
2002\end{array}$ \\
\hline Barry Brakey & $\begin{array}{l}\text { Australian Property } \\
\text { Institute }\end{array}$ & 2,000 & $\begin{array}{l}\text { December, } \\
2002\end{array}$ \\
\hline John Wilson & Engineers Australia & 2,300 & March, 2003 \\
\hline Tony Arnel & Building Commission & 2,600 & $\begin{array}{l}\text { September, } \\
2003\end{array}$ \\
\hline & Average & 2,275 & \\
\hline
\end{tabular}

Table 1: Analysis of interview transcript

* Full interview transcripts published The Building Economist on the dates stated

\section{PUBLIC RECOGNITIONAND STATUS}

The interviewees all spoke about the need for public recognition and status. This resulted from the perception that professional societies seemed to be dependant on maintaining high levels of educational and professional experience of their members.

The institutes represented in this paper all require at least a degree level qualification and a number of years professional work experience from applicants for membership. In addition, government registration in Victoria requires that professionals in designated professions contain a level of Professional Indemnity (PI) insurance and maintain an ongoing program of continuing professional development (CPD).

This was expressed very clearly by the president of the RAIA who stated that 'most of all I think the membership has always wanted the Institute to be active in the public sphere, to represent the benefits of architects to the community... that is what the Institute is there to do!' She went on to suggest that: 
I believe we try to say to the public: here is a profession that has high skills, high level of education, high level of practical experience, and a profession that has a humanist and broad social knowledge base. So, we are not just technical people we have a bit of professionalism, and we understand a lot about many things. The best way we can serve the community, and clients, is to be the best that we can be.

A similar view was expressed by the Building Commissioner who believes that:

Registration establishes a minimum level of qualification and experience that provides a reasonable guarantee of a good service being provided. This in turn delivers satisfaction to the consumer of (professional) services. It's a three-way link between the quality of practitioner, quality of product (professional service), and the level of satisfaction experienced by the consumer.

The largest of the institutes interviewed was Engineers Australia (EA), which has a total of 69,000 members nationally. According to their president, EA have recently invested in a trial television advertising campaign in Adelaide. The campaign comprises a series of short fifteensecond television advertisements, which are followed up by newspaper advertisements in the daily papers aimed at providing more detailed information.

The aim of the advertising was to educate clients, and the community at large, about the quality and skills of engineers. The president mentioned that the brand recognition campaign was designed to inform the public of quality standards by which engineers should be recognised. $\mathrm{He}$ believed that there was a link between community recognition and professional status.

Each institute president concluded that promotion of the profession was an important component of what professional societies are supposed to do. The objective of the promotion was to establish credibility and status for the professional members of the institute.

\section{MAINTENANCE OF PROFESSIONAL STANDARDS}

One of the aims of this paper was to examine the mechanisms used by professional societies to ensure that their members maintain their professional credibility and relevance to their clients. All the respondents spoke about the need to provide CPD for their members. For the purposes of this research CPD is considered to be approved post-qualification training for people engaged in the construction industry. Training required to obtain initial qualifications is not considered to be CPD.

According to a recent report (Building Commission, 2003):

CPD is expected to yield important benefits in terms of improved overall productivity within the building industry as well as reducing the cost of building disputes and the associated need for rectification work to be undertaken. It is also expected to improve the public standing of affected building occupations.

According to the Building Commission (2003) the CPD requirements are expected to yield important benefits in terms of reduced incidence of building disputes, as well as general productivity gains within the industry. In addition, the government regulator intends to make CPD a compulsory legal requirement for all Registered Building Practitioners in Victoria.

All professional societies encourage ongoing maintenance of CPD for their members. The role of CPD is considered very important to the practice of any professional discipline. This research demonstrates that CPD is central to the operation of professions today, and this was fully supported by the interviewees. According to the API President, 'the point we have made to our members is that it's not about which seminar is offered by API, it's about what an individual member does to maintain their own professional competence'.

The results show (Table 2) that all interviewees consider that compulsory CPD was an important aspect of being a professional person, and all are prepared to enforce it.

\begin{tabular}{|l|l|}
\hline $\begin{array}{l}\text { Organization } \\
\text { Royal Australian } \\
\text { Institute of Architects }\end{array}$ & $\begin{array}{l}\text { The view of many is that it should be } \\
\text { made compulsory for architects because } \\
\text { it is another way that the profession } \\
\text { can demonstrate its commitment to } \\
\text { excellence. }\end{array}$ \\
\hline $\begin{array}{l}\text { Australian Property } \\
\text { Institute }\end{array}$ & $\begin{array}{l}\text { As an Institute we remain committed to } \\
\text { our (compulsory) CPD policy. }\end{array}$ \\
\hline Engineers Australia & $\begin{array}{l}\text { We have a policy to undertake a random } \\
\text { audit (of CPD) of about 10\% of all } \\
\text { Chartered Professional Engineers each } \\
\text { year and any person who does not } \\
\text { complete the minimum level of CPD can } \\
\text { lose their title. }\end{array}$ \\
\hline Building Commission & $\begin{array}{l}\text { CPD will be a requirement of the law } \\
\text { (in Victoria), and therefore we expect } \\
\text { registered building practitioners to } \\
\text { comply. }\end{array}$ \\
\hline
\end{tabular}

Table 2: Support for compulsory CPD

The cost of compliance with CPD however, represents an impost on professional people. Hence, the issue is whether the cost of compliance with CPD is likely to produce sufficient benefits to the profession as a whole. It was obvious from the interviewees that the benefits of mandatory CPD may not be appreciated by some of the members of professional societies. A number of negative comments were advanced which show that the compulsory CPD is likely to be a contentious issue for many institute members 
The quotes shown in Table 3 suggest that the industry leaders perceive that in some cases their members may be doubtful about the benefits of CPD. This seems to indicate that mandatory CPD may cause some dissatisfaction to some to professionals.

\begin{tabular}{|l|l|}
\hline $\begin{array}{l}\text { Organization } \\
\text { of Architects }\end{array}$ & $\begin{array}{l}\text { Comments } \\
\text { I think we need to broaden what } \\
\text { is understood by CPD by making } \\
\text { it something that is multi-faceted } \\
\text { and something that a lot of people } \\
\text { can get benefit and indeed can } \\
\text { contribute to. }\end{array}$ \\
\hline Australian Property Institute & $\begin{array}{l}\text { I would hope that the counselling } \\
\text { process, which goes along with } \\
\text { the discipline procedures, helps } \\
\text { members to see the importance } \\
\text { of CPD }\end{array}$ \\
\hline Engineers Australia & $\begin{array}{l}\text { The CPEng (professional) title } \\
\text { includes a requirement for } \\
\text { maintaining CPD of } 50 \text { hours } \\
\text { per year. This ... is a national } \\
\text { initiative and signifies that any } \\
\text { person who achieves this status is } \\
\text { qualified and competent to practice } \\
\text { independently as an engineer. }\end{array}$ \\
\hline Building Commission & $\begin{array}{l}\text { The Building Commission is } \\
\text { committed to an education process } \\
\text { to inform the industry of the new } \\
\text { requirements before it becomes } \\
\text { mandatory. }\end{array}$ \\
\hline
\end{tabular}

Table 3: Reservations and negative comments about compulsory CPD

It has become obvious that the industry leaders interviewed believe that the CPD issue is sufficiently important for the president to take a strong 'leadership' position on the matter. This seems to have occurred in spite of the perceived reservations of some of their members. In addition, all professional institutes supported the position taken by the government regulator to mandate compulsory CPD as part of registration. It is worth noting that all institutes offer low cost CPD seminars to their members; this benefit has the effect of improving the value of membership of a professional society.

\section{BENEFITS OF MEMBERSHIP}

The third objective of this research was to probe interviewees' beliefs about the way in which they provide direct benefits for their members. It became obvious in the discussion with the presidents of the Australian Property Institute and Engineers Australia, that their members perceived Profession Indemnity (PI) insurance is an issue that impacts on their professions.

Almost without exception professionals operating in a commercial environment must have some form of $\mathrm{PI}$ insurance. In addition, $\mathrm{Pl}$ is mandatory for registered building practitioners in Victoria, so each registrant must be insured in order to participate in the industry.
All interviewees made the link between $\mathrm{PI}$ insurance and quality of professional service provided. Although PI insurance is a legal requirement, there was a belief that professionals that maintain a high level of professional competence are likely to provide their clients with better quality advice and therefore are less likely to be sued by their clients they serve.

In addition, the president of the API suggested that failure to provide competent services on the part of a few undisciplined members has the potential to increase $\mathrm{PI}$ premiums for all members. The API quote in Table 4 demonstrates that he perceives that members would like the institute to act forcefully on those who provide services which are less than what would be considered as professionally acceptable. This demonstrates that professional societies have an incentive for maintaining and enforcing ethical standards on their members.

\begin{tabular}{|l|l|}
\hline Organization & Comment \\
\hline $\begin{array}{l}\text { Australian Property } \\
\text { Institute }\end{array}$ & $\begin{array}{l}\text { The biggest issue that we have at } \\
\text { the moment is professional indemnity } \\
\text { insurance. (Some of our) ... members are } \\
\text { under enormous pressure because they } \\
\text { are considered to be a high-risk category. } \\
\text { I think our members are looking to the } \\
\text { Institute to be harder on people who are } \\
\text { not acting in a professional way. They } \\
\text { would like to see the API act on discipline } \\
\text { matters more quickly, and more vigorously. }\end{array}$ \\
\hline Engineers Australia & $\begin{array}{l}\text { PI insurance is an extremely important } \\
\text { and relatively complex issue. In the } \\
\text { long-term we are suggesting to insurers } \\
\text { that members who have attained CPEng } \\
\text { (professional) status represent a lower } \\
\text { risk than others. We are hopeful that } \\
\text { the CPEng status will reduce the cost of } \\
\text { insurance and therefore benefit our clients } \\
\text { and the community. }\end{array}$ \\
\hline Building Commission & $\begin{array}{l}\text { We are mindful of insurance issues } \\
\text { and this is something that the Building } \\
\text { Commission has been working on for } \\
\text { some time and takes very seriously. It is } \\
\text { important that the building industry has } \\
\text { reasonable access to insurance services in } \\
\text { order to keep it functioning properly. }\end{array}$ \\
\hline
\end{tabular}

Table 4: Attitude to the increasing cost of PI Insurance

The results of the interviews also show that the professional institutes perceive a role in negotiating on behalf of their members with the insurance industry. Both the Building Commission and Engineers Australia have been in lengthy discussion with the insurance industry in order to reduce premiums for selected groups of their members.

It would seem logical to suggest that negotiations are likely to be more successful if individual institutes can join forces with other kindred organizations. In addition, the government regulator stated that their 'role was one that encourages the 
building industry to continue without undue encumbrance. This requires us (Building Commission) to intervene when a crisis develops in the industry, in this case the lack of supply of insurance'.

\section{CONCLUSIONS}

This research sought the views of several leaders in the property and construction industry. It records the attitudes of a group of people who are in a strong position to understand the complexity of professional societies. In many respects their attitudes are similar; all support the maintenance of high levels of education, training and CPD. There was a perception that these were all essential characteristics of what has been termed 'professionalism' by Eccles (2002). This is based on the notion that the community needs confidence in the integrity of professionals.

Each of the industry leaders concluded that the public status of their profession was important.

Public recognition is a significant part of the responsibility of professional societies, at least in the minds of their Presidents. It was summed up neatly by the Engineers Australia President:

I think members see profile raising as an important aspect of what the Institution does for its members ... If the profile can be raised it has a number of positive effects, including more demand for university courses, and our members are in a stronger negotiating position with employers over pay and conditions.

The industry leaders suggested that professionals need to keep up-to-date and relevant to their clients and the community. It was suggested by the Building Commissioner that CPD is 'expected to improve the public standing of building occupations'. Results of the interviews showed that CPD was an important component of maintaining community confidence in the professions, and that the institutes should be seen to be actively promoting its benefits.

One of the aims of this exploratory research was to determine how institutes provide benefits to their members. The issue of the rising cost of $\mathrm{PI}$ insurance premiums has forced professional societies to act in the interests of their members. The Building Commission and Engineers Australia have been negotiating directly with insurance providers on behalf of their members. The objective has been to broker exclusive deals for their members that would not have been possible for individual members.

In addition, the president of the API mentioned that one of the roles of the institute was to 'act on discipline matters more quickly and more vigorously' in the interest of other members. This was seen as necessary to ensure that insurance premiums remain as low as possible, and to give the impression that their members have professional credibility.
The greatest imperative of institutes is their long-term role to ensure the community receives value in the provision of professional services. What is concluded in this paper is that public status, maintenance of skills, and ethical standards, will remain the main objectives of professional societies. However, it may be reasonable to suggest that in the future institutes will need to be more strategic in their operation and rely less on reactive approaches. In future it is suggested that professional societies will need to discuss their roles more actively their members and the community than they have in the past.

\section{REFERENCES}

Building Commission (2003). Continuing Professional Development for the Building Industry Practitioner Survey Report, Building Commission, Government of Victoria.

Easterby-Smith, M., Thorpe, R. and Lowe, A. (1991). Management research: An introduction. Sage Publications, London.

Eccles, T. (2002). Professional Development: Balancing Globalism, Sustainability and Tradition. ICEC World Congress, Environmental and Economic Sustainability: Cost Engineering Down Under. Melbourne.

Fowler, F. (1984). Survey research methods: Applied social science methods series. Sage Publications, London.

Hughes, W. (ed) (2003). De-professionalised, automated construction procurement, Building Futures, Commission for Architecture and built environment, and Royal Institute of British Architects, London.

Mills, A. (2002a). The Architects. The Building Economist, September, 32-34.

Mills, A. (2002b). Rules of conduct and practice standards. The Building Economist, December, 18-20.

Mills, A. (2003a). The Engineers: the role of professional institutes today, The Building Economist, March, 29-32.

Mills, A. (2003b). The role of the government regulator. The Building Economist, September, 9-13.

MRS (1973). A handbook for interviewers. Market Research Society, Hobbs the Printer, London. 
